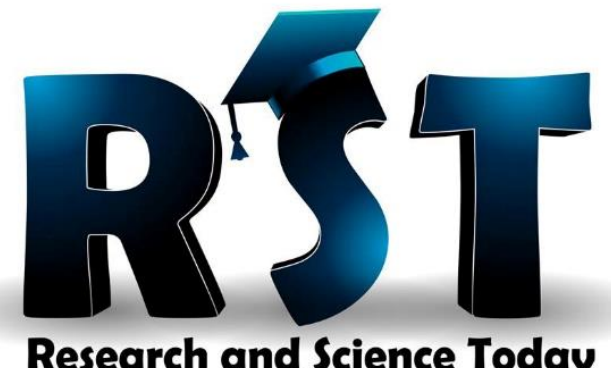

\title{
DOI: 10.38173/RST.2020.S1.6:47-53
}

Title: CONTRIBUTION OF NON-VIRAL RISK FACTORS TO DEVELOPMENT OF HEPATOCELLULAR CARCINOMA

\section{Amelia GENUNCHE-DUMITRESCU}

Daniela BADEA

Authors:

Cristian MARINASุ

Daniela NEAGOE

Mihail BADEA

Tiberiu-Stefaniță ȚENEA-COJAN

Section: Medical Sciences

Issue: $\quad$ Supplement 1/2020

Received: 15 March 2020

Accepted: 26 April 2020
Revised: 9 April 2020

Available Online: 2 June 2020 


\title{
CONTRIBUTION OF NON-VIRAL RISK FACTORS TO DEVELOPMENT OF HEPATOCELLULAR CARCINOMA
}

\author{
Amelia GENUNCHE-DUMITRESCU ${ }^{1}$ \\ Daniela BADEA ${ }^{2}$ \\ Cristian MARINAȘ ${ }^{3}$ \\ Daniela NEAGOE ${ }^{4}$ \\ Mihail BADEA ${ }^{5}$ \\ Tiberiu-Stefaniță ȚENEA-COJAN ${ }^{6}$
}

\begin{abstract}
:
THE HEPATOCELLULAR CARCINOMA IS ONE OF FREQUENTLY TYPES OF THE PRIMARY LIVER CANCER IN ADULTS AND IS THE MAIN CAUSE OF DEATH IN PATIENTS WITH LIVER CIRRHOSIS. THE MAJOR RISK FACTOR FOR LIVER CANCER IS CHRONIC INFECTION WITH HEPATITIS B VIRUS (HBV) OR HEPATITIS C VIRUS (HCV). THE RISK OF DEVELOPEMENT OF THE LIVER CANCER IS INCREASED IN THE PATIENTS WITH CIRRHOSIS. ALSO, NON-VIRAL FACTORS SUCH AS OBESITY, DIABETES MELLITUS, ALCOHOL CONSUMPTION AND/OR NON-ALCOHOLIC FATTY LIVER DISEASE (NAFD) WAS IMPLICATED IN THE DEVELOPMENT OF HEPATOCELLULAR CARCINOMA.
\end{abstract}

KEY WORDS: HEPATOCELLULAR CARCINOMA, HEPATIC VIRUS, NON-VIRAL FACTORS.

\section{INTRODUCTION}

Hepatocellular carcinoma (HCC) is one of the most common malignant tumors, representing more than $5 \%$ of all cancers. HCC it is also is the fifth most common cancer in the world and the third leading cause of cancer related deaths in the world ${ }^{7}$.

\footnotetext{
${ }^{1}$ Clinical Hospital of Emergency Craiova, $1^{\text {st }}$ Medical Clinic, University of Medicine and Pharmacy Craiova, Romania;

${ }^{2}$ Clinical Hospital of Emergency Craiova, Department of Physiology, University of Medicine and Pharmacy

${ }^{3}$ Clinical Hospital of Emergency Craiova, Department of Anatomy, University of Medicine and Pharmacy Craiova, Romania

${ }^{4}$ Clinical Hospital of Emergency Craiova, $1^{\text {st }}$ Medical Clinic, University of Medicine and Pharmacy Craiova, Romania

${ }^{5}$ Filantropia Hospital Craiova, Department of Clinical Hematology, Craiova, Romania

${ }^{6}$ CFR Hospital, Surgery Department, University of Medicine and Pharmacy Craiova, Romania

7 El-Serag HB, Rudolph KL, Hepatocellular carcinoma epidemiology and molecular carcinogenesis, Gastroenterology 2007, 132, 2557-76; Mittal S., El-Serog HB., Epidemiology of hepatocellular carcinoma
} 
Liver cirrhossis and chronic hepatitis $\mathrm{B}$ and $\mathrm{C}$ represent the major factor for development of hepatocellular carcinoma. Also, in a significantly percent of the HCC patients $(15 \%-20 \%)$ both markers of hepatitis B virus and hepatitis C virus infection show the absence of viral causes of HCC. The most frequently non-viral risk factors of HCC was diabetes mellitus, chronic alcohool consumption, obesity, non-alcoholic fatty liver disease (NAFLD) or non-alcoholic steatohepatitis (NASH), primary biliary cirrhosis (PBC), iron overload syndrome, tobacco and pesticide exposure ${ }^{8}$.

The most patients with hepatocellular carcinoma had a history of heavy alcohol intake. Alcohol consumption in patients with chronic hepatitis accelerates the process of fibrosis with an increased risk for progression to cirrhosis and hepatocellular carcinoma ${ }^{9}$.

The number of HCC patients classed as Child-Pugh A was greater than the number with advanced cirrhosis. The risk of HCC development is much greater in men for the majority of aetiologies.

Multiple non-viral factors have been implicated in the development of $\mathrm{HCC}^{10}$. Increased body mass index in association with diabetes and subsequent development of nonalcoholic steatohepatitis (NASH) represent significant risk factors for HCC. The risk of development hepatocellular carcinoma and the duration of the progression of the liver disease in type 2 diabetes mellitus depending significantly on the duration of diabetes and therapy. Type 2 diabetes has been linked with an increased risk of liver cancer, usually in patients who also have other risk factors such as alcohol abuse and/or chronic viral hepatitis ${ }^{11}$. The obesity contributes to the development of various diseases including diabetes, hypertension, cardiovascular and cerebrovascular and is also known as a risk factor of cancer. Obesity was associated with increased mortality in many cancer such as: esophagus, colorectal, stomach, breast and liver cancer. Association of the obesity with chronic hepatitis $\mathrm{C}$ have a higher risk of HCC and visceral adiposity is strong correlated with carcinoma. Obesity may also influence HCC prognosis, body mass index (BMI) seems to be a predictor of microvascular invasion and poor prognosis, while visceral adiposity is associated with $\mathrm{HCC}$ recurence, after treatment.

\section{OBJECTIVES}

The aim of our study was to assess the role of non-viral causes, as independent risk factors, in development of hepatocellular carcinoma (HCC).

\section{METHODS}

We studied retrospectively 188 patients which developed HCC in the last six years, with mean age of $(53.17 \pm 3.24$ years), structured in two groups: the A group consist of patients with hepatitis $B$ virus and hepatitis $\mathrm{C}$ virus infection and the $\mathrm{B}$ group contain $\mathrm{HCC}$ patients with non-viral aetiology.

consider the population, Journal of Clinical Gastroenterology 2013, 47 Suppl S2-6; De Lope CR, Tremosini S, Forner A, Reig M and Bruix J: Management of HCC, Journal of Hepatology 56, (Suppl 1): S75-S87, 2012

${ }^{8}$ Manal A Hamed, Sanaa A Ali, World Journal of Hepatology 2013, June 27, 5 (6): 311-322

${ }^{9}$ De Lope CR, Tremosini S, Forner A, Reig M and Bruix J: Management of HCC, Journal of Hepatology 56, (Suppl 1): S75-S87, 2012

${ }^{10}$ Manal A Hamed, Sanaa A Ali, World Journal of Hepatology 2013, June 27, 5 (6): 311-322

11 Dyal HK, Aguilor M, Bartos G., Hoet EW, Bhuket T., Liu B, Cheung R, Wong RJ., Diabetes mellitus increases risk of hepatocelular carcinoma in chronic hepatitis $C$ virus patients: a systematic review, Digestive Disease and Sciences, 2016, 61, 636-45 
Fig. 1: The structure of the whole group of patients: viral vs non-viral aetiology

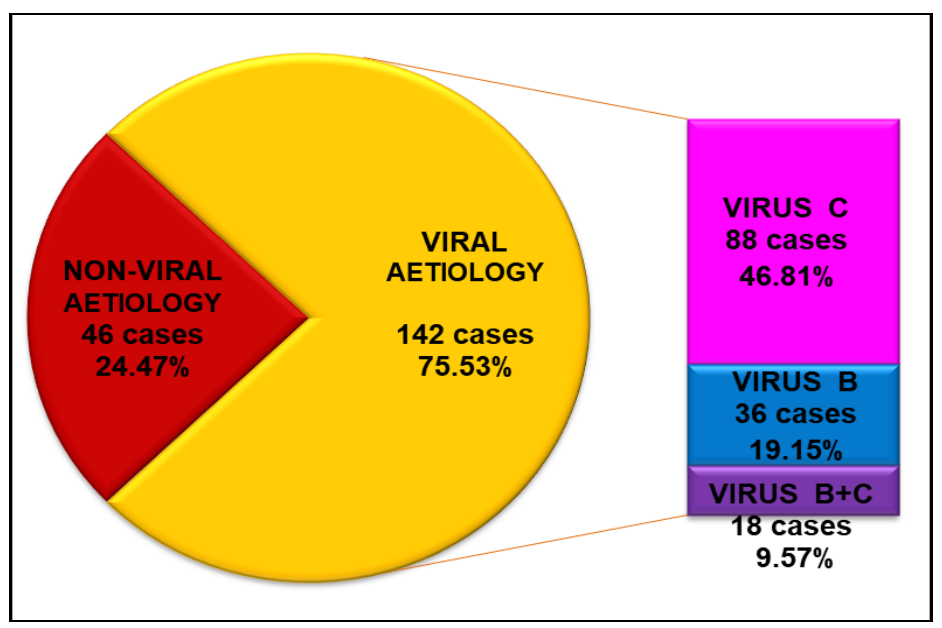

The diagnosis was established by clinical picture, laboratory parameters, imagistic and histological exams. Ultrasonography underestimate the exact number of nodules and Doppler ultrasonography may observe the local extension of a hepatocellular carcinoma in the main portal vein. For a certain of the diagnosis, any focal liver lesion detected by ultrasonography should be confirmed by either other imaging method (CT; RMN) or liver biopsy and histological analysis. Multifocal liver lesion and satellite nodules are two frequent types of HCC. We monitored the serum alpha fetoprotein level at each 3 months. The disease evolution was evaluated, according CLIP score and Okuda staging system, after 3, 6, 9 and 12 months after diagnosis.

\section{RESULTS}

The viral aetiology of HCC (A group, 142 cases) was predominant (75.53\%): virus $\mathrm{C}$ ( 88 cases), virus B (36 cases), B+C virus (18 cases). Also, in a significantly percent of whole group, HCC has a non-viral aetiology (group B, 46 cases, 24.4\%): alcohol-induced liver disease (20 cases), primary biliary cirrhosis (3 cases), diabetes mellitus (9 cases), obesity associated with NASH (8 cases) and other aetiology (6 cases).

Fig. 2: The structure of the B group of patients function by aetiology of HCC

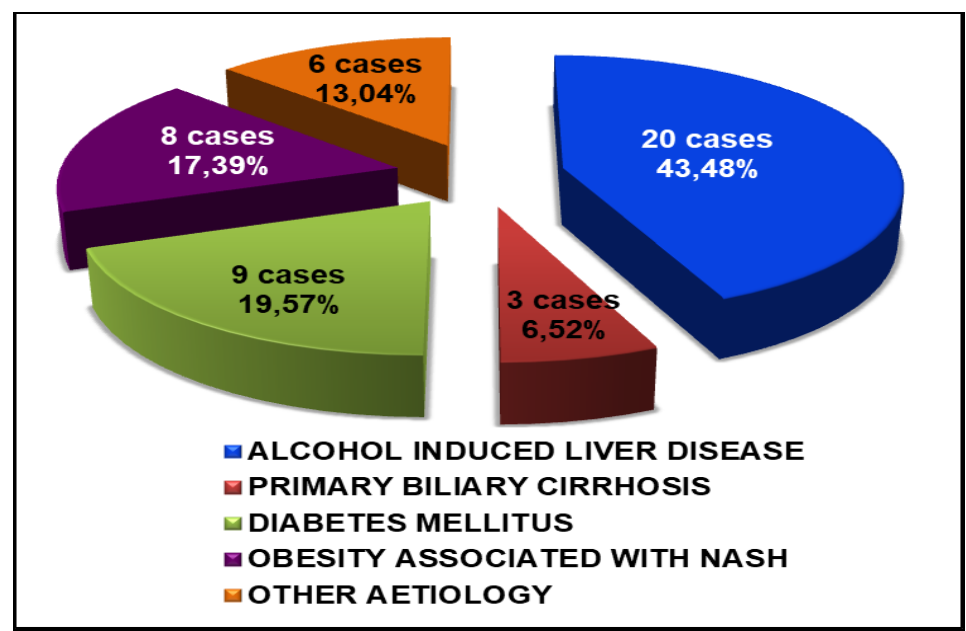




\section{RST}

Alcohol abuse increased likelihood to develop HCC in 85 cases: in 65 cases in association with viral aetiology $(45.77 \%)$ and in 20 cases $(43.4 \%$ of non-viral aetiology) as non-viral risk factor. The structure of the group function by alcohol consumption grade was: non-alcoholic or never drinking patients (20 cases), 8 patients with history of alcohol consumption but non-alcoholic in the last three years, occasional consumers or low dose alcohol intake (10 cases, < $40 \mathrm{~g} /$ day), 28 patients with chronic alcohol consumption (between 40 and $80 \mathrm{~g}$ daily) and 16 cases of heavy drinker patients (more than $80 \mathrm{~g}$ alcohol daily).

Fig. 3: Alcohol abuse: independant or associated risk factor in development of HCC

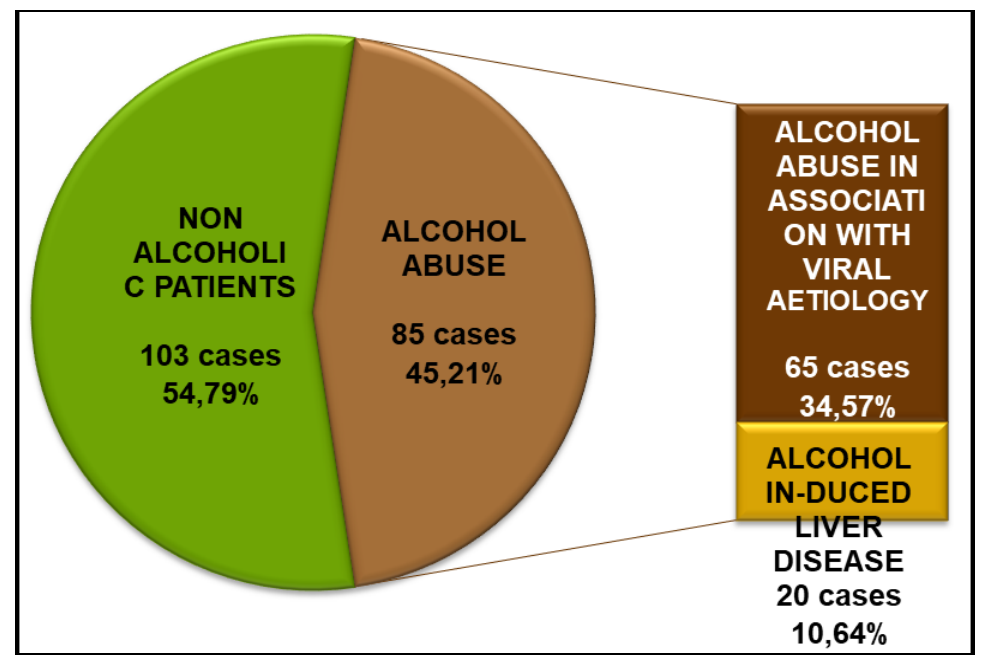

Diabetes mellitus was present in 34 cases, but in 19 cases was associated with virus infection. The association between diabetes mellitus and development of the HCC was more frequent in patients without hepatitis B virus or hepatitis C virus infection: 13.38\% (19 cases) in the A group versus $32.61 \%$ (15 cases) in the B group.

Fig. 4: The association between diabetes mellitus and development of the HCC

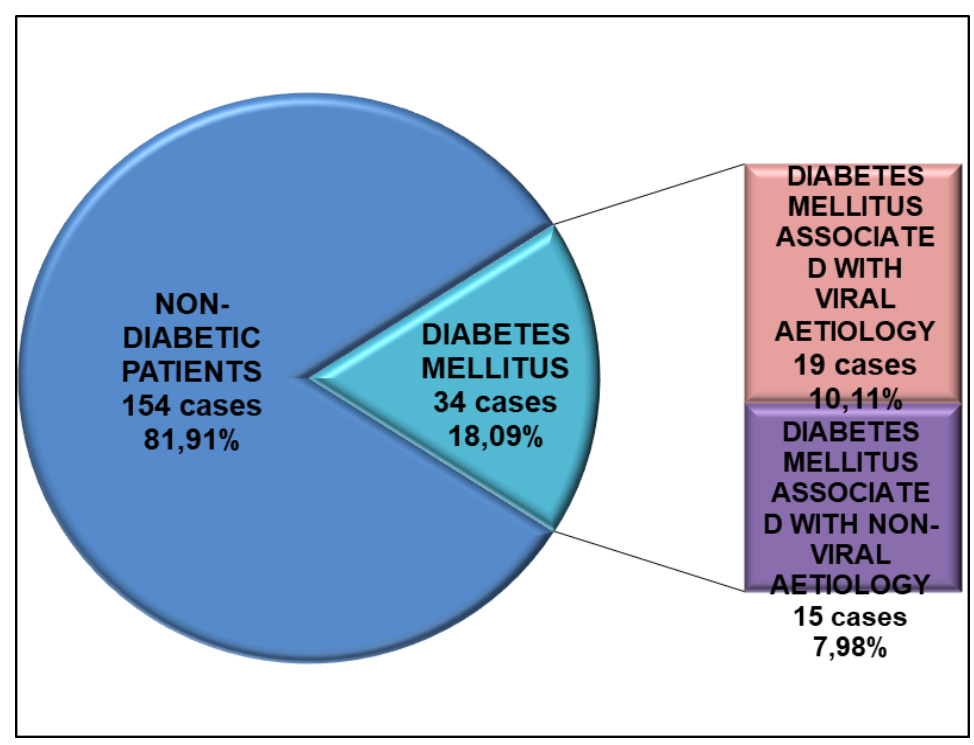


The presence of diabetes remained an independent risk factor for HCC after exclusion viral hepatitis, alcohol use, PBC or other causes, in 5 cases $(10.87 \%)$. In the others 10 cases $(21.74 \%)$ the diabetes mellitus was associated with other risk factors such as chronic alcohol consumption (6 cases), obesity ( 7 cases), NAFLD (3 cases).

The prevalence of NASH in the B group (HCC with non-viral aetiology) was $41.30 \%$ (19 cases) but only in $17.39 \%$ of patients ( 8 cases) developed HCC. In all this 8 cases the NASH was associated with obesity and in three of this patients we observed severe or morbid obesity (BMI greather than $40 \mathrm{~kg} / \mathrm{sqm}$ ).

Obesity was present in majority of HCC patients (105 cases, 55.32\%), but its incidence was higher in non-viral aetiology of HCC: $78.26 \%$ (36 cases) in B group comparative with $47.89 \%$ (68 cases) in the A group.

Fig. 5: The association between aetiology of the HCC and chronic alcohol consumption

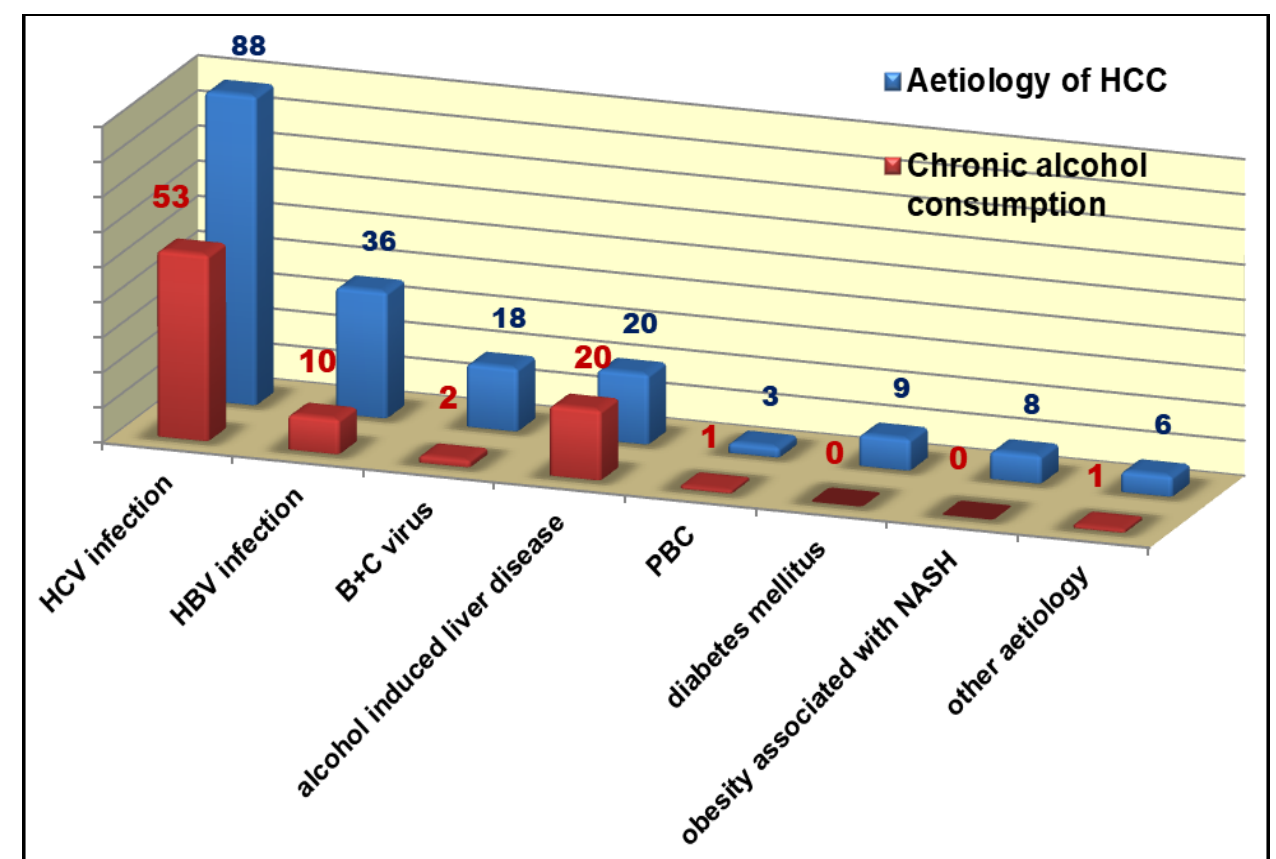

HCC was developed in cirrhotic patients in 118 cases: 81 cases with HBV or HCV infection and 37 cases with non-viral aetiology. Cirrhotic patients were classed as Child-Pugh A (60 cases), Child-Pugh B (38 cases) and Child-Pugh C (20 cases). The type of HCC was: solitary ( 82 cases), paucifocal (2-3 nodules) in 60 cases, multifocal ( $>3$ nodules) in 33 cases and diffuse in (13 cases). Majority of the solitary HCC presented nodules with dimensions between two and five centimeters: $<2 \mathrm{~cm}$ (12 cases), $2-5 \mathrm{~cm}$ (51 cases) and $>5 \mathrm{~cm}$ (19 cases). Partial or complete portal vein thrombosis was present in 43 cases: in 29 patients with $C$ virus, in 13 with B virus and only in one case without virus. 


\section{RSI}

Fig. 6: The type of HCC in patients with non-viral aetiology of the HCC (B group, 46 cases)

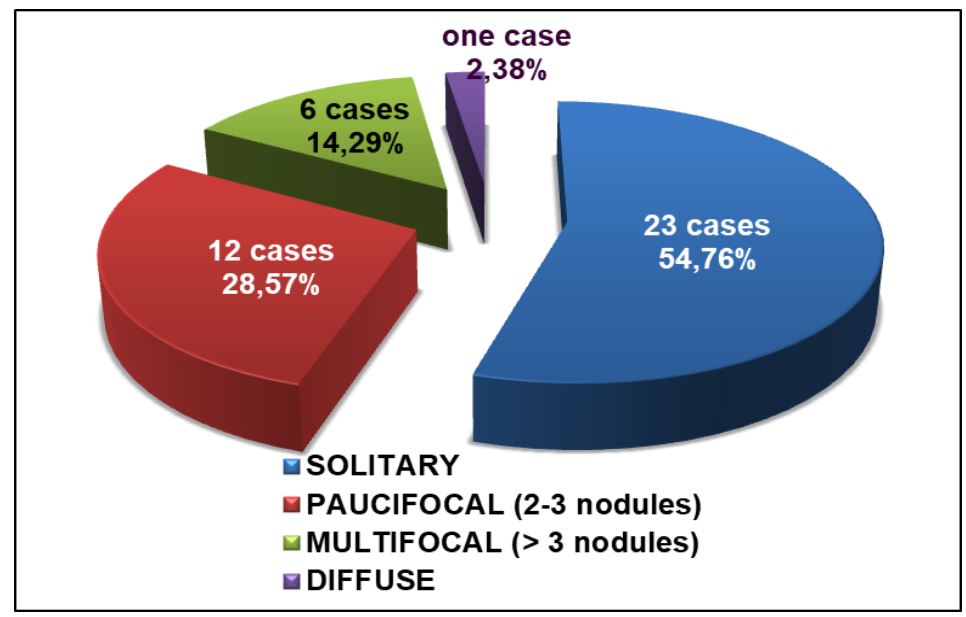

Association of $\mathrm{C}$ virus infection with alcohol abuse was correlated with tumour dimensions $(\mathrm{r}=0.308, \mathrm{p}=0.001)$. The values of glycated hemoglobin and BMI were not correlated with tumour dimensions.

Presence of the diabetes mellitus was correlated with an increased risk of HCC, compared with non-diabetic patients and association between diabetes mellitus, obesity and dyslipidemia determined in many cases a rapid progression of chronic liver disease and HCC development. Also, after the HCC diagnosis, in patients who associated diabetes mellitus, obesity and dyslipidemia the mean value of the CLIP score increased from 2.67 at baseline to 3.3 at 6 months and to 4.1 at 12 months. Comparatively, in non-diabetic patients the increase of the mean values of the CLIP score was significantly reduced and slowly from 2.5 at baseline to 2.85 at 6 months and 3.25 after 12 months.

\section{CONCLUSION}

Multiple non-viral factors have been implicated in the development of HCC.

Obesity, diabetes mellitus, non-alcoholic fatty liver disease all contribute to a higer HCC risk and operate as independent risk factors. The risk of HCC was even greater if both obesity and diabetes were present in comorbid condition.

Association of presence of $\mathrm{C}$ virus and alcohol abuse, in HCC patients, was correlated with tumour dimensions.

\section{ACKNOWLEDGEMENT}

All authors had the same contribution.

The authors declare that they have no conflict of interests. 


\section{SuPPLEMENT 1/2020}

ISSN-E: 2344-0007 / ISSN-L: 2344-0007

\section{REFERENCES}

1. Turati F, Galeone C, Rota M, Pelucchi C, Negri E, Bagnardi V, et al., Alcohol and liver cancer: a systematic review and meta-analysis of prospective studies, Annals of Oncology, 2014;25:1526-1535.

2. Torres DM and Harrison SA, Nonalcoholic steatohepatitis and noncirrhotic hepatocellular carcinoma: fertile soil, Seminars in Liver Disease, 32: 30-38, 2012.

3. Yasui k, Hashimoto E., Komorizone, Koikak, Arii S et al., Characteristics of patients with nonalcoholic steatohepatitis who develop hepatocellular carcinoma, Clinical Gastroenterology and Hepatology, 2011, 9, 428-33.

4. Takuma Y and Nouso K, Nonalcoholic steatohepatitis-associated hepatocellular carcinoma: our case series and literature review. World Journal of Gastroenterology, 16: 1436-1441, 2010.

5. Polesel J., Zucchetto A, Montella M, Dal Maso L, Crispo A et al. The impact of obesity and diabetes mellitus on the risk of hepatocellular carcinoma, Ann Oncol 2009; 20: 353-357.

6. Stickel F., Alcoholic cirrhosis and hepatocellular carcinoma, Advances in Experimental Medicine and Biology, 2015;815:113-130.

7. El-Serag HB, Rudolph KL, Hepatocellular carcinoma epidemiology and molecular carcinogenesis, Gastroenterology 2007, 132, 2557-76;

8. Mittal S., El-Serog HB., Epidemiology of hepatocellular carcinoma consider the population, Journal of Clinical Gastroenterology 2013, 47 Suppl S2-6;

9. De Lope CR, Tremosini S, Forner A, Reig M and Bruix J: Management of HCC, Journal of Hepatology 56, (Suppl 1): S75-S87, 2012;

10. Dyal HK, Aguilor M, Bartos G., Hoet EW, Bhuket T., Liu B, Cheung R, Wong RJ., Diabetes mellitus increases risk of hepatocelular carcinoma in chronic hepatitis $C$ virus patients: a systematic review, Digestive Disease and Sciences, 2016, 61, 636-45;

11. Kamel IR, Bluemke DA., Imaging evaluation of hepatocellular carcinoma, Journal of Vascular and Interventional Radiology, 2002;

12. Tabor E., Hepatocellular carcinoma: global epidemiology. Digestive and Liver Disease, 2001; 33; 115-117;

13. Manal A Hamed, Sanaa A Ali, World Journal of Hepatology 2013, June 27, 5 (6): 311-322;

14. Lee TY, Wu JC, Yu SH, Lin JT, Wu MS, Wu CY., The occurrence of hepatocellular carcinoma in different risk stratifications of clinically non-cirrhotic non-alcoholic fatty liver disease, International Journal of Cancer, 2017, https://doi.org/10.1002/ijc.30784. 